TEME, г. XLI, бр. 4, октобар - децембар 2017, стр. 1113-1137

Оригинални научни рад

DOI: $10.22190 /$ TEME1704113V

Примљено: 3. 12. 2016.

UDK 796.032.2-055.2:316.774

Ревидирана верзија: 9. 7. 2017.

Одобрено за штампу: 15. 11. 2017.

\title{
WOMEN AND OLYMPIC GAMES: MEDIA COVERAGE
}

\author{
Marija Vujović", Marta Mitrović, Neven Obradović \\ University of Niš, Faculty of Philosophy, Niš, Serbia \\ *marija.vujovic@filfak.ni.ac.rs
}

\begin{abstract}
Despite the fact that women have succeeded in their effort to have equal participation in the Summer Olympics, the public image of them is still predominantly stereotyped, which this study proves. The subject of analysis in this paper are narrative articles and photographs about male athletes and female athletes in sports sections, especially in the Olympic specials and the front pages of the best-selling daily newspaper in Serbia, Blic, during the Olympic Games, from July 27th to August 13th 2012. Hypotheses that the authors want to prove deal with the assumption that male athletes are often more represented in media than female athletes, and that the articles about women are often stereotyped. Some of the most frequent stereotypes are those which describe women as feminine, beautiful or sexual objects, as well as like someone's mother, wife or girlfriend, also, as infantile, emotional or irritable, or maybe those are just some irrelevant articles that do not talk about sport activities of female athletes. The Olympic Games in London are significant because, for the first time in history, women were equated with men in the sports in which both genders participate.
\end{abstract}

Key words: $\quad$ women, sport, Olympic games, media, gender stereotypes.

\section{ЖЕНЕ И ОЛИМПИЈСКЕ ИГРЕ: МЕДИЈСКО ИЗВЕШТАВАЊЕ}

\footnotetext{
Апстракт

Упркос чињеници да су се жене избориле за равноправно учешће на Летњим олимпијским играма, медијска слика о њима и даље је претежно стереотипна, што ово истраживање и доказује. Полазећи од чињенице да су жене у спорту маргинализоване, о чему сведочи и мањи проценат учесница наспрам учесника на Олимпијским играма, аутори полазе од претпоставке да медијско представљање одсликава такву стварност и да су жене спортисткиње у медијима мање заступљене, али и стереотипно приказане. Предмет анализе у раду су наративни текстови и фотографије на којима су приказани мушкарци спортисти и жене спортисткиње у спортским рубрикама, посебно у оквиру Олимпијског специјала и насловним странама најтиражнијег дневног листа у Србији - у Блицу, од 27. јула до 13. августа 2012. године, у периоду одржавања Олимпијских игара. Хипотезе које аутори доказују су да су мушкарци спортисти медијски чешће праће-
} 
ни од жена и да су текстови о женама често стереотипни. Међу стереотипима се издвајају они који жену приказују као женствену, лепотицу или сексуални објект, као нечију мајку, супругу или девојку, као инфантилну, емотивну и раздражљиву, или је реч о нерелевантним текстовима који се не односе се на спортске активности жене спортисткиње. Олимпијске игре у Лондону значајне су јер су тада жене, први пут у историји, изједначене са мушкарцима у спортовима у којима учествују.

Кључне речи: жене, спорт, Олимпијске игре, медији, родни стереотипи.

\section{INTRODUCTION}

The question of women's participation in public activities is the subject of numerous studies in various fields, such as politics, economy, technology, and media (Thomas \& Bond, 2015; Alsos, 2016). Public events, traditionally reserved for men, have served as scenes of the "struggle" of women to enter these fields and have equal treatment. Sport is a valid example of such a public event, while the status of women in the sports events is one of the examples of their marginalization and stereotyping which is still present. Given the fact that the Olympic Games can be seen as the culmination of sporting achievement, but also as a significant media event, they are a suitable subject of analysis, which can be used to point out the inequality of women in sport, and in sports media coverage. While printed media increases print runs, adding special pages dedicated to this event, the direct television broadcasts, especially of the opening of the summer Olympics have been media spectacles in modern history that bring multimillion audiences around the world in front of the television screens, and the directors win awards. According to the data of the Olympic Marketing Fact File, and International Olympic Committee, Summer Olympic Games in London in 2012 were seen by the record of more than three and a half billion people around the globe, and the record was hit on digital channels as well. Moreover, the revenue from media contracts exceeded two and a half billion dollars (Olympic Marketing Fact File, 2014, p. 23-26). In this context, the Olympic Games, as the male event, are considered to be a media spectacle and very profitable, and as such they are a very good research topic for the author whose goal is to emphasize "women's space" in this, historically, masculine domain. The Games, as a sport event with a long tradition, are suitable for an analytical approach to chronological involvement of women in sport, while their global popularity is suitable for drawing conclusions about how women are unequally treated in terms of media reporting even when they are equally involved in the event.

In addition to quantitative differences in media coverage of women participating in the Games when compared to male athletes, there is a stereotype matrix of participants, which the authors have confirmed in 
this paper by performing quantative and qualitative analysis. Overall conclusion of previous research also refers to the emphasis of the inferiority of women's sports disciplines compared to men's.

Starting from these assumptions, in the research part of the paper, the authors attempted to use quantitative and qualitative analysis of content in sports sections, especially in The Olympic Specials and the front pages published during the Olympic Games in London (27 July - 13 August $^{1}$, 2012) in the most popular newsletter in Serbia - Blic (www.mc.rs/blic-najcitaniji24-sata-i-alo-ispred-informera.6.html?eventId $=67263$ ), and to confirm the initial hypotheses relating to a smaller coverage of women's sports in the Olympics in 2012, as well as the presence of stereotyped reporting about female participants in the Games, expressed through the narrative texts and photographs. The Games in London are a valuable example for the analytical approach since the first time in the history of the Olympics, women were included in all Olympic disciplines, and the proportion of their participation has reached a record high of 44.2 percent, which was a record until then ${ }^{2}$. It is interesting that the most numerous teams (of the USA and Russia) had more female athletes, who also won more medals. That was not the case in Serbia team. Out of 115 Serbia Olympic team members, there were only 36 women, that is, $31 \%$, but they still won half of the medals for Serbia (www.oks.org.rs/takmicenja/olimpijskeigre/letnje-olimpijske-igre/xxx-igre-london-2012).

\section{WOMEN AND OLYMPICS}

The Olympic Games started in the Peloponnese in Greece, "nobody knows exactly when they began, but the first written mention of them dates back to 776 BC" (The Olympic Games in Antiquity, 2013, p. 3). Although the modern Games, renewed in 1896 in Athens, differ greatly from the ancient Games, one of the common traits could be the equal interest in researching the presence or absence of women in this event, traditionally linked to males. There are contradictory statements regarding the participation and presence of women in general in the ancient Olympic Games, which is probably a result of subsequent myths, which made it difficult to distinguish between historical facts and legends. Allegations range from those that women were prohibited to even watch the Games, to those that only unmarried women could watch the competition (The Olympic Games in Antiquity, 2013); however, there are some statements that women

\footnotetext{
${ }^{1}$ The last day of the Olympic Games in London in 2012 was on 12 August, while the newspapers wrote about the events of that day in the edition of 13 August.

2 During the 2016 Olympic Games in Brazil, the record was broken. Women's participation increased to 45 percent (Factsheet women in the Olympic Movement, 2016).
} 
also competed in the ancient times. The number of participants is negligible, but it is certainly a significant fact if we approach it from the aspect of the struggle of women to be the participants in these male events.

„There were never any women's events or categories in the ancient Olympics. Several women Olympic victors, however, appear in the official lists [...] The first and most notable of these women victors was Kyniska of Sparta, who won the four-horse chariot race in 396 BC“" (Young, 2004, p. 13).

Gender equality issues, as well as most of modern problems and issues that are the topics of numerous researchers and theorists certainly were not significant in ancient times. A lot has changed in the perception of women's roles from ancient times to the start of the modern Olympics in 1896. Female breakthrough into men's domain was lengthy and complex, both concerning the Games, and the traditional men's sports events. Pierre de Coubertin, the founder of modern Olympic Games, and the long-time president of the International Olympic Committee was not in favor of women as contestants. At the first modern Olympic Games all athletes were men. "[...] although one woman, Melpomene, who was banned from running in the marathon, still ran the whole track together with male athletes" (Skembler, 2007, p. 91). At that time, female athletes faced many prejudices. People worried that they would lose their femininity, over-develop their muscles or become sterile (The Modern Olympic Games, 2013). The Olympic debut of women was at the Olympics in Paris in 1900, when they competed in tennis and golf, while female participants constituted 2.2 percent of all participants ${ }^{3}$. Yet, that did not stop Coubertin to write a sexist and discriminatory text in 1912, which was published in his journal Revue Olympique:

„In our view, this feminine semi-Olympiad is impractical, uninteresting, ungainly, and, I do not hesitate to add, improper. It is not in keeping with my concept of the Olympic Games, in which I believe that we have tried, and must continue to try, to put the following expression into practice: the solemn and periodic exaltation of male athleticism, based on internationalism, by means of fairness, in an artistic setting, with the applause of women as a reward" (Coubertin, 1912, p. 713 according to Polley, 2014, p. 30-31).

This excerpt from a newspaper article greatly sheds light on social and political climate of the overall attitude towards women and their socially-built, inferior role in those times. However, even some

\footnotetext{
3 "Despite the reticence of the reviver of the modern Games, Pierre de Coubertin, 22 women out of a total of 997 athletes competed in just five sports: tennis, sailing, croquet, equestrian and golf. But only golf and tennis had events for women only "(Factsheet women in the Olympic Movement, 2016).
} 
modern theorists are of an opinion that sport is not for women. Sociologist John Carroll believes that women are by nature destined to be mothers and housewives, and that sport threatens that role. On the other hand, men are brave, destined to struggle in sports arenas (Carroll, 1985, p. 91-98 according to Đulijanoti, 2008).

Despite the initial negative attitude of the founders, women have gradually fought for their place in the Olympics, which is reflected both in the continuous increase in the number of participants, and in their participation in various sports. It is an interesting fact that in the groundbreaking 1900 Olympics, women's participation percentage was higher than in the next three Olympic years. Only since 1920, the percentage of female participants began to grow, while since 1964 it has been constantly growing, and at the Summer Olympics in London in 2012, that number reached a record of 44.2 percent (Factsheet women in the Olympic Movement, 2016). It took more than a century for women to compete on equal terms in all sports at the Olympics. In this respect, the Olympics in 2012 was a milestone. The introduction of female boxing category has marked, practically and symbolically, the victory of women after a century of struggle.

"The arrival of women in the ring intimated that the old Olympic model of what a sports woman should be like was being laid to rest, while the admission of women into such a masculine preserve was a tacit recognition that the lines distinguishing male from female sport were becoming blurred" (Polley, 2014, p. 30).

Yet, perhaps the celebratory conclusion might blind us and prevent us from seeing the shades of equality, which is certainly not unambiguous.

"There are fewer weight classes in freestyle wrestling and boxing and there are still events women do not participate in, including the $50 \mathrm{~km}$ race walk, shooting events, and some canoe/kayak events, as well as Greco Roman wrestling. Even when the number of events in a sport is equal for men and women, men outnumber women in those events" (Smith \& Wrynn, 2014, p. 58).

However, as Donnelly and Donnelly (2013) state in their research, nine sports at the Summer Olympics in London were reserved for women only; such as, rhythmic gymnastics and synchronized swimming. ${ }^{5}$

\footnotetext{
4 "Female participation has increased steadily since then, with women accounting for more than 44 per cent of the participants at the 2012 Games in London, compared with 23 per cent at the Games in 1984 in Los Angeles and just over 13 per cent at the 1964 Games in Tokyo"(Factsheet women in the Olympic Movement, 2016).

${ }^{5}$ Donnelly and Donnelly conducted a survey which analyzed the 2012 Summer Olympics from the perspective of gender equality. The authors dealt in detail with men's and women's sports and the differences between them (Donnelly \& Donnelly, 2013).
} 
Although the status of women in the Olympics nowadays is incomparable with the treatment of women in the beginnings of the modern Games, and in particular with their exclusion in ancient times, it still seems that "the masculine Olympic motto of Citius, Altius, Fortius ("Faster, Higher, Stronger") still dominates" (Polley, 2014, p. 30).

However, the increase in the number of women in the competition was not accompanied by their corresponding increase in the management structures of the Olympics. Although the International Olympic Committee (IOC) ordered that the National Olympic Committee (NOC), International Federations (IF) and the National Federation (NF) reserve at least 20 percent of management positions for women,

"[...] twenty-seven NOCs (of 135 who participated in the IOC survey) have 30 percent or more women on their Executive Board. 62 NOCs have less than 20 percent of women on their Executive Boards and 10 NOCs still have no women on their Executive Board" (Factsheet women in the Olympic Movement, 2016, p. 2).

In order for women to really be equal participants in the Olympics, it is not enough to provide them with visibility only in the competition. The real indicator of the status of women in sport, and society in general is reflected in their participation in the management structures. ${ }^{6}$ According to Toohey and Veal (Toohey \& Veal, 2007) the predominant presence of men in governing structures has influenced the position of women in sports; women are in a position that is reflected in constant struggle and frequent need to justify their own successes.

Political and cultural struggle of women to win the men's sphere is evident along the entire structure of society at all its levels. If every public event has traditionally been associated with the activities of men, then, on the symbolic level, conquering the sports sphere is one of the most obvious examples of struggle between femininity and masculinity. Gender is clearly referred to in any sport article.

In recent decades, sport has become almost exclusively a media product; therefore, another essential aspect of the analysis of gender equality in sports is media representations of sports events.

"As a result of the co-dependent relationship between the mass media and sport, which has developed over time, the media have now become one of the key benefactors, and key beneficiaries, of institutionalized sport and, as such, have become

\footnotetext{
6 "In 1990, for the first time in the history of the IOC, a woman was elected on to the Executive Board (Flor Isava Fonseca), and in 1997, another woman, Anita DeFrantz, became an IOC Vice-President (1997-2001)“ (Factsheet women in the Olympic Movement, 2016).
} 
a forceful site for constructing gender discourse and fashioning hegemony“" (Toohey et al., 2007, p. 206).

Media are often referred to as a mirror of social, political and cultural times. Deconstruction of media content, the creation of which is certainly affected by the dominant hegemonic constructs of a society, could lead us towards the answer to the question of which social groups are marginalized, which are subordinate, and which are the superior ones. However, "how and what constitutes media coverage of sport can be investigated only by moving away far beyond from the world of sport" (Blain \& Boyle, 2005, p. 631). Such an approach will only be achieved if the analysis does not lose sight of the cultural and ideological aspect, and if it uses the theoretical foundation resting on feminism.

\section{WOMEN, MEDIA AND OLYMPIC GAMES}

The relationship between the media and the Olympic Games, according to Slater (Slater, 1998, p. 49-68) is observed through four phases, conditioned by technical innovations: Time before television (1894 - 1932), time of television, before the satellites (1936 - 1964), time of satellite television, before the Internet $(1968$ - 1988) and time of Olympics domination (1992 and onwards). Undoubtedly, television is the medium which has been most responsible for global popularity, but also for the availability of the Olympic Games. From one country, Germany, who organized the first television coverage of the summer Olympic Games in Berlin in 1936, that number has grown to two hundred and twenty countries in the $21^{\text {st }}$ century, ending with the year 2012 in London (Olympic Marketing Fact File, 2014, p. 22).

In sports, as well as in other spheres of public life, gender is a construct, while masculinity and femininity are culturally and historically determined.

"Numerous arguments based on biological distinctions, some of which are that women, because they are physically weaker, give birth and breastfeed children should be naturally tied to their home and family, are opposed by feminists who note that the position of women is actually determined not by the biological characteristics, but rather by social and economic status, as well as by historical and cultural understanding" (Vulić \&Vujović, 2012, p. 61).

In accordance with the dominant patriarchal ideology, men are expected to be active, rational, brave, aggressive, combative and women to be passive, emotional, gentle, good (Jakšić, 2002, p. 41-58). Despite the numerous social, political and economic changes in the $21^{\text {st }}$ century, such gender stereotypes survive, and major role in keeping it that way have the mass media. 
"When the media persistently portray women and men in certain ways, these ways of presentation are accepted as the norm. Media content that encourages stereotypes, exclusion, prejudice and uncritical thinking lead to severe gender inequality" (Sola, 2009, p. 29).

Female athletes are faced with such gender stereotypes, especially in the environments where gender differences are more frequent. By observing sport as an exclusively male discipline, women are put in a position to experience their body as masculine, thus coming out of the "ordinary" (Toohey et al., 2007). This situation can be explained by the dominant hegemonic model of masculinity.

"Historically though, in most societies, sport has been the embodiment of hegemonic masculinity, an avenue by which males can demonstrate their superiority over females. To participate in sport is often an empowering experience for males, but it has often been less so for females" (Connell, 1995, p. 77).

Thus, the dominant model of masculinity in western cultures is hegemonic masculinity, which includes heterosexuality, homophobia and misogyny. It also implies dominance, power, rationality, and public sphere as the sphere of men. All other models of masculinity and femininity are its subordinates. Another argument from those who have marginalized women in sports through history is that men are physically superior, and sport is, in most of the world, culturally destined for men, because it implies activity, but not for women, who are expected to be passive.

Generally, media representation is affected by multiple factors. In addition to the dominant ideological matrix, political and economic factors are also indispensable, as well as the preconceptions of professional communicators.

"This means that sport in the media is very important not only economically but also politically and ideologically [...], and, since the journalists and editors are actually privileged jobs, we should have in mind that the ideologies that are produced or reproduced by the mainstream media, when discussing topics related to sports, tend to belong to the ideologies of socially dominant groups" (Blain at al., 2005, p. 634).

In this respect, if we accept the feminist claims that, despite the indisputable historical progress in the position of women, the traditional patriarchal matrix is still dominant in most spheres of social life, the conclusion to be made is that the representation of women in the media is the reflection of such order. We start with this assumption when we begin with theoretical considerations of media representations of women in the Olympic Games. 
The process by which media coverage imposes certain socially and culturally constructed reality, through the selection of information, photos, quotes, thus moving away real types from the system of representation, is called framing in the media studies. "Frame analysis could, simply speaking, be defined as a way to interpret reality by its participants" (Zvijer, 2012, p. 1074). Reality is therefore constructed, not naturally given. When the consumers of media content once adopt this system of representation, they find it very difficult to change it, because they constantly reapply it when processing any new information from a specific topic pre-framed by the media.

If women who participate in sports events are primarily marginalized, and when they do appear in these events, the media presents them in such a way that stereotypes are confirmed or even reinforced, media audience will not notice anything wrong about this type of portrayal, because the media have been presenting women in such a way that it now seems "natural" to the audience.

Media portrayal of female athletes is largely based on stereotypes, suggesting that women were uninvited (and perhaps unwanted) but still entered traditionally male space and area. Such a reporting undermines the importance of the success of female athletes. By constantly returning and referring to the logic of patriarchy, female athletes can be successful if, in addition, media texts, implicitly, and sometimes explicitly associate them with their imposed roles, with those which are placed in the private domain, or who are overexposed as an object that is available to males. Thus, Wensing and Bruce recognize five media "rules" for the creation of female athletes in a subordinate, culturally specific gender role: gender emphasis identify a sports event as a female; compulsory heterosexuality - presenting female athletes as a sexual object, someone's girlfriend, wife or mother; the emphasis on femininity - female athlete is portrayed as gentle, beautiful, dependent; a female athlete is infantized - when addressing the athlete with "young girl" or "young lady" or just with her first name; and, finally, present the facts which are not relevant to the sport, but only for personal life or appearance of the female athlete (Wensing \& Bruce, 2003, p. 387396). It is clear that with such media coverage, women's sports cannot be equal with men's. In the media, men are shown superior to women, their sports accomplishments and abilities are often camouflaged with the story of their gender roles, or physical characteristics.

So, there is no doubt that the media build gender hierarchy in sports through their narrative and visual messages which are dominated by "strong" men against "weak" women, while male sport is valued more than female sport. Such a hierarchy is supported by advertisers, as well as by close associates of media. Media both marginalize women in sport, and often trivialize their sports activities and successes. The attractiveness of female athletes is often the ticket for media attention. "At sports 
events, voyeuristic cameras tread through the crowd and find shots of attractive, half-dressed ladies in the audience, but also among the athletes" (Đulijanoti, 2008, p. 140). Often, female athletes themselves agree to be photographed nude or in sexy dresses, usually under the pretext of advertising the sport. However, “ [...] self-sexualization is a strategy of desperate to raise interest among the audience, which is dominated by men and to get the support of corporations" (Đulijanoti, 2008, p. 141).

Cheryl Cooky, et al. (2015) updated a 25-year longitudinal study on the coverage of women sport in television news and found that coverage was extremely low. They have concluded that men football, basketball and baseball are still the most covered sports. Also, the results of their analysis show a decrease in the representation of athletes as sexual objects, but an increase in their representation as mothers. The authors emphasize a significant qualitative difference in the representation of men and women sports; while stories about male sports are always exciting and dramatic, stories about women sports are often boring, and reduced to mere facts.

Ronald Bishop (2003) analyzed some articles from the Olympic years each month in the first issue of Sports Illustrated for six years. Media coverage of women from 1980 to 1996 was compared with the analysis from the Olympic years from 1956 to 1976 . The author analyzed texts and photos related to the Olympic Games, the total number of articles by issue, athletes gender, the number of pages per article and the type of sport in each article. Bishop's results show that media coverage of male athletes in the analyzed years 1980-1996 was 80\%, and in the last twenty years there was no significant increase in the representation of female athletes.

When it comes to the study of printed media, one of the studies (Embrey, Hall, \& Gunter, 1992, p. 10-13) investigates the reporting of three influential daily newspapers in Australia during the Olympic year of 1992. The conclusion is that the newspapers write about women's participation in sports activities at an average of 29.3 percent, which is significantly above the average of 4.2 percent with regard to the period beyond the Olympic Games, and this percentage approximately coincides with the percentage of female participants in the Olympics. This could be explained by the fact that national affiliation is more dominant at the Olympic Games than gender.

Similar results were shown by other studies. Capranica and other authors (Capranica et al., 2005, p. 212-223) did a survey on coverage of women's sports during the 2000 Olympic Games in Sydney, Australia, in newspapers in Belgium, Denmark, France and Italy, and concluded that the percentage of media coverage coincides with the percentage of participation of men and women. Therefore, they concluded that there is a trend of equalization of men and women when it comes to media coverage, which they associated with the efforts of the International Olympic Committee to achieve gender equality. However, the quantitative increase does not necessarily imply the qualitative one. Although present in the media, women 
are often portrayed as sexual objects, someone's girlfriend or wife, etc. while their sport achievements are disregarded.

Interesting research on the media coverage of men's and women's basketball on sport web sites, Facebook and Twitter pages of Southeastern Conference institutions was conducted by Steve Shih-Chia Chen et al. (2016). Their analysis shows that media coverage of men's sport is slightly higher than for women's (by around 6\%). Also, some schools that were included in their analysis had more websites for female athletes than for male athletes. These authors believe that these new, modern media platforms can, if not overcome, then at least reduce the marginalized and stereotyped representation of female athletes.

Toohey and Veal conclude that women's sport get less attention in the media when compared to the sports activities of men. The authors cite a survey of press done in Australia, conducted by Murray Phillips (Phillips, 1997 according to Toohey et al., 2007, p. 195) and which concluded that women are less represented athletes that are rarely found on the prestigious first and last pages of newspapers, and that reports about them are more frequently published midweek. The authors note a survey that display gender on television stations in the United States, as part of the study conducted by The Amateur Athletic Foundation of Los Angeles.

"Anita DeFrantz, president of the foundation, IOC member and former IOC Vice - President, noted in her foreword to the report that: 'the continued paucity of women's stories occurs against the backdrop of significant growth of girls' and women's sports nationally and internationally, a development that is simply ignored by television sports news. The willful neglect of women's sports is an abdication of journalistic responsibility and has the effect of diminishing the significance of women's sport, while hindering its further growth" (DeFrantz, 2005, p. 3).

The problem of the presence, or absence, and the representation of female athletes in the media is particularly denominated during the Olympic Games. This was the main topic of "Media Workshop on Women and Sport", held in Doha (Qatar) in 2015. Lydia Nsekera, President of the IOC Women and Sport Commission, emphasized on that occasion the inferior treatment of women in sports reporting and urged the media to cooperate:

"It is a shame that, more often than not, the coverage, marketing and promotion of women's sport is based on gender. It is unacceptable that female athletes are defined by their body type or their beauty, to the detriment of their athletic or leader ship qualities. [...] May I ask you, each of you concerned, to go back determined to promote and popularize women's sport and to make a firm commitment to ensuring an increase in women's coverage in the media? And, above all, to provide a non-discriminatory image of female athletes in the media? By working together, the media, 
politicians and sports officials, as well as other partners, we will be able to redress the balance! [...] Dear media friends, on behalf of the women in the Olympic Movement, I ask you to help us win this battle" (www.olympic.org/news/doha-media-workshop-calls-forcommitment-to-lead-the-change-in-women-s-sport/245322).

Olympics Games in 2012, specific by the participation of women in all sports, could have been a turning point in the method of reporting on women's sports; however, that did not happen. Based on the study which was conducted by Packer et al in 2012 and published in 2014, a quantitative analysis of media coverage of the Olympic participants in the UK showed the following results:

"In 2012, 39 of 876 articles in national newspapers (4.5 percent) related to women's sports [...] 24 of 647 pictures (3.7 percent) related to women's activities". However, compared with 2013, which was a non-Olympic year, there were slightly more articles written: the total number of articles in 2013 was 2.9 percent, while the percentage of photos was 1.4 percent (Packer et al., 2014, p. 50).

Although media coverage of women in sport is a topic that preoccupies theorists all over the world, especially in the US, Australia and Europe, starting from the nineties of the $20^{\text {th }}$ century ${ }^{7}$, who are managing to prove that the media reflect the ideology of male superiority in sport and marginalize women (Lee, 1992; Shifflett, Revelle, 1994; Daddario, 1994; Pirinen, 1997; Lenskyj, 1998; Jones, Murrell, \& Jackson., 1999; Pedersen, 2002; Bishop, 2003; Shields, Gilbert, Shen, \& Said, 2004; Capranica, et al., 2005), such research is rare in Serbia. One such research was done by some authors within the publication Report on Sport - introduction of gender dimension (Đorđić et al., 2013), as part of the project done by the Women's Support Center from Kikinda, called Change of Media Practice in Reporting on Women in Sport. Djordjic examined the photos of female athletes in the daily Dnevnik, published in one week in November 2011. The results show that the representation of women in sports photographs for the observed period is significantly lower in comparison with men. Individually or in group, men were present on $90.5 \%$ of photos, while women were only present in $5.5 \%$ of photos. Mixed sports photos were represented by 4 percent. The same is true when it comes to photographs on the front pages male athletes are in 95 percent of photographs (Đorđić et al., 2013, p. 45). In another survey carried out over one month, from mid-November to mid-

\footnotetext{
${ }^{7}$ The question of the status of women in sport, and media coverage of female athletes was raised by liberal feminists in the 60's. Advocating for the democratic principles of equality, and conscious power of the media, they believed that the media, through a certain way of portrayal of females can naturalize their position, and maintain the status quo.
} 
December in 2011, on a sample of nineteen copies of newspapers and seven news TV shows on the territory of Vojvodina, using the method of quantitative and qualitative analysis of media discourse, Pralica and Milinov came to the following results: in print media, women are mentioned in 24 percent of sports texts, most often through factual genres, without any further analysis, and in more than half of the photographs female athletes are passive. When it comes to television reporting, female athletes are mentioned in 33 percent of sports TV shows, exclusively in reports, and they rarely speak (Pralica \& Milinov, 2013, p. 48-52).

\section{RESEARCH}

Motivated by this fact, the authors of this paper carried out the study using the method of quantitative and qualitative content analysis ${ }^{8}$, with the aim to:

1. Identify the total number of sports narrative articles and photographs, the number of articles relating to male athletes, female athletes and mixed texts in sports sections, especially in The Olympic Specials and front pages of the daily newspaper Blic, during the Olympic Games (from July $27^{\text {th }}$ until August $13^{\text {th }} 2012$ );

2. Recognize gender stereotypes about women in the narrative sports articles and photographs relating to female athletes, in sports sections, especially in The Olympic Specials and front pages of the daily newspaper Blic, during the Olympic Games (from July $27^{\text {th }}$ until August $13^{\text {th }} 2012$ );

Thus, the subject of analysis are narrative texts and photographs, in sports sections, especially in The Olympic Specials and front pages of the daily newspaper Blic, during the Olympic Games (from $27^{\text {th }}$ July to $13^{\text {th }}$ August 2012), which speak about and which depict sport activities of male athletes and female athletes at the Olympics. The analysis included all types of narrative articles and documentary photographs. Obvious photomontages and graphic representations were not the subject of the analysis. The studied sample is the biggest circulation newspaper in Serbia, Blic, during the Olympic Games (from $27^{\text {th }}$ July to $13^{\text {th }}$ August 2012), or, for a period of 18 days.

\footnotetext{
${ }^{8}$ According to Srbobran Branković (Branković, 2009), content analysis is the most suitable method to analyze media content, including photographs. Although primarily determined as quantitative, this method is also qualitative. Apart from describing and classifying content, this method also places it in a time and space context.
} 
Hypotheses from which the researchers started were the following: 1.In the daily newspaper Blic, during the Olympic Games (from $27^{\text {th }}$ July to $13^{\text {th }}$ August 2012), in sports sections, especially in The Olympic Specials and front pages, there were more narrative articles and photographs about male athletes than about female athletes;

2. The majority of narrative articles and photographs relating to female athletes in the daily newspaper Blic, during the Olympic Games (from $27^{\text {th }}$ July to $13^{\text {th }}$ August 2012) in sports sections, especially in The Olympic Specials and front pages is stereotypical (texts are irrelevant, they do not refer to female athletes sports activities, one athlete is portrayed as feminine, beautiful, sex object; another female athlete is portrayed as someone's mother, wife, girlfriend; one more athlete is portrayed as infantile, emotional, irritable).

\section{RESULTS}

Total number of narrative articles and photographs within the sample is 625,289 of which are narrative (46.2 percent), while there were 336 photographs, or 53.8 percent. Total number of narrative articles and photographs relating to female athletes is 181 , which is 29 percent in relation to the total number of articles. From these articles, 80 articles or 12.8 percent are narrative, while a greater number of texts, 101 total, or 16.2 percent are photographs. More than twice as more articles were published about male athletes -414 total, or 184 (29, 4 percent) narrative articles, and 230, or 36.8 percent photographs. There were 30 mixed narrative articles and photographs, out of which 25 (or 4 percent) were narrative, and 5 (or 0.8 percent) were photographs (Table 1, Table 2).

Based on the obtained results, the authors conclude that during the Olympic Games in London in 2012, the daily newspaper Blic published more than twice as many narrative articles and photographs of male athletes than female athletes (Graphic 1).
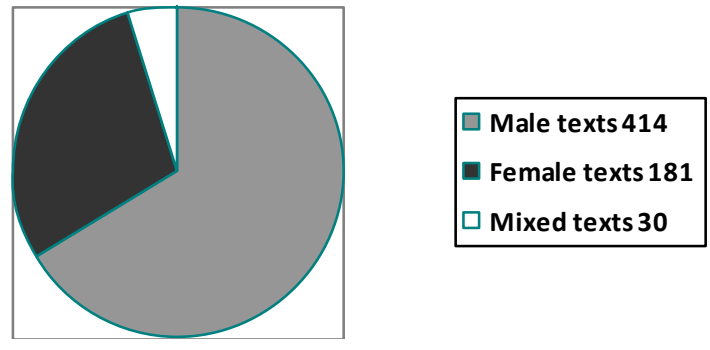

Graphic 1. Female, male, and mixed sport texts in newspaper Blic (27 July $-13^{\text {th }}$ August 2012) 
These results have proven the initial hypothesis that the daily newspaper Blic published more narrative articles and photographs on male athletes than on female athletes in their newspaper sports section, and especially in The Olympic Specials and front pages. The authors also observed that there were more photographs than narrative articles published on female athletes which would be in accordance with Berger's statement: "Men act and women have looks. Men look at women [...] Femininity is usually encoded as passive (to be, to have looks), while masculinity is seen as active (to have, to possess)" (Berger, 1972, p. 42).

Table 1. Female, male, and mixed narrative sport texts in newspaper Blic $\left(27^{\text {th }}\right.$ July $-13^{\text {th }}$ August 2012)

\begin{tabular}{lrr}
\hline & \multicolumn{2}{c}{ Blic } \\
\cline { 2 - 3 } & $\mathrm{N}$ & $\%$ \\
\hline Female narrative texts & 80 & 12,8 \\
Male narrative texts & 184 & 29,4 \\
Mixed narrative texts & 25 & 4,0 \\
\hline Total narrative sport texts & 289 & 46,2 \\
\hline
\end{tabular}

Table 2. Female, male, and mixed photographs in newspaper Blic (27 July $-13^{\text {th }}$ August 2012)

\begin{tabular}{lrr}
\hline & \multicolumn{2}{c}{ Blic } \\
\cline { 2 - 3 } & $\mathrm{N}$ & \multicolumn{1}{c}{$\%$} \\
\hline Female photographs & 101 & 16,2 \\
Male photographs & 230 & 36,8 \\
Mixed photographs & 5 & 0,8 \\
\hline Total photographs & 336 & 53,8 \\
\hline
\end{tabular}

When we talk about gender stereotypes in the narrative texts and photographs which refer to female athletes, the authors identify the following stereotypes (Table 3, Table 4):

- Female athletes are shown in the irrelevant texts, which do not refer to their sports activities. This is the case in 10 percent of the narrative, and 13.9 percent of photographs.

- Female athletes are represented as feminine, beautiful, sexual objects (photo 1, photo 2). This is the case in 1.3 percent of narrative texts, and 5 percent of photographs.

- Female athletes are represented as someone's mother, wife, and girlfriend (photo 3 , photo 4). This is the case in 5 percent of narrative texts, and 2 percent of photographs.

- Female athletes are represented as infantile, emotional, and irritable. This is the case in 10 percent of narrative, and even 26.7 percent of photographs. 
- When observing the overall scores, in terms of narrative texts, female athletes are stereotypically shown in 26.3 percent of cases, but when it comes to photographs, female athletes are stereotypically represented in as many as 47.5 percent of the cases.

By examining the second hypothesis separately, through stereotypes, and in particular through the narrative texts and photographs, the second hypothesis, according to which most of the narrative articles and photographs relating to female athletes in the daily newspaper Blic during the Olympic Games (from $27^{\text {th }}$ July $13^{\text {th }}$ August 2012) in sports sections, especially in The Olympic Specials and front pages are stereotypical, was not confirmed. However, when looking at all narrative texts and photographs, and at all the stereotypes observed, the percentage of stereotypical coverage is 73.8 percent, which is an indicator of the dominant stereotypical reporting on female athletes.

Table 3. Female gender stereotypes in narrative texts in newspaper Blic $\left(27^{\text {th }}\right.$ July $-13^{\text {th }}$ August 2012)

\begin{tabular}{lrr}
\hline & \multicolumn{2}{c}{ Blic } \\
\cline { 2 - 3 } & $\mathrm{N}$ & $\%$ \\
\hline All female narrative sport texts & 80 & 100 \\
Narrative text is irrelevant; it does not refer to sports & 8 & 10 \\
activities of female athletes & 1 & 1,3 \\
$\begin{array}{l}\text { Narrative article represents female athlete as feminine, } \\
\text { beautiful, sexual object }\end{array}$ & 4 & 5 \\
$\begin{array}{l}\text { Narrative article represents female athlete as someone's } \\
\text { mother, wife, girlfriend }\end{array}$ & 8 & 10 \\
$\begin{array}{l}\text { Narrative article represents female athlete as infantile, } \\
\text { emotional, irritable }\end{array}$ & 21 & 26,3 \\
All stereotypical narrative female sport texts & & \\
\hline
\end{tabular}

Table 4. Female gender stereotypes in photographs in newspaper Blic $\left(27^{\text {th }}\right.$ July $-13^{\text {th }}$ August 2012)

\begin{tabular}{lrc}
\hline & \multicolumn{2}{c}{ Blic } \\
\cline { 2 - 3 } & $\mathrm{N}$ & $\%$ \\
\hline $\begin{array}{l}\text { All female sport photographs } \\
\text { Photograph is irrelevant; it does not refer to sports }\end{array}$ & 14 & 16,2 \\
activities of female athletes & 5 & 5 \\
$\begin{array}{l}\text { Photograph represents female athlete as feminine, } \\
\text { beautiful, sexual object }\end{array}$ & 2 & 2 \\
$\begin{array}{l}\text { Photograph represents female athlete as someone's } \\
\text { mother, wife, girlfriend }\end{array}$ & 27 & 26,7 \\
$\begin{array}{l}\text { Photograph represents female athlete as infantile, } \\
\text { emotional, irritable }\end{array}$ & 48 & 47,5 \\
\hline All stereotypical female sport photographs & & \\
\hline
\end{tabular}


Examples of stereotypical coverage of female athletes in the narrative texts and photographs have been confirmed by the previous quantitative overview. However, when identifying stereotypes, authors applied qualitative content analysis of The Olympics Specials. A qualitative example of a stereotype where a female athlete was shown as a sexual object in a photograph published on July 27, 2012. (photo 1). Although the female athlete was shown at the sports field, the focus is on her physical attributes. This photograph, together with the title "Beauty and skill" can be undoubtedly seen as a stereotype.

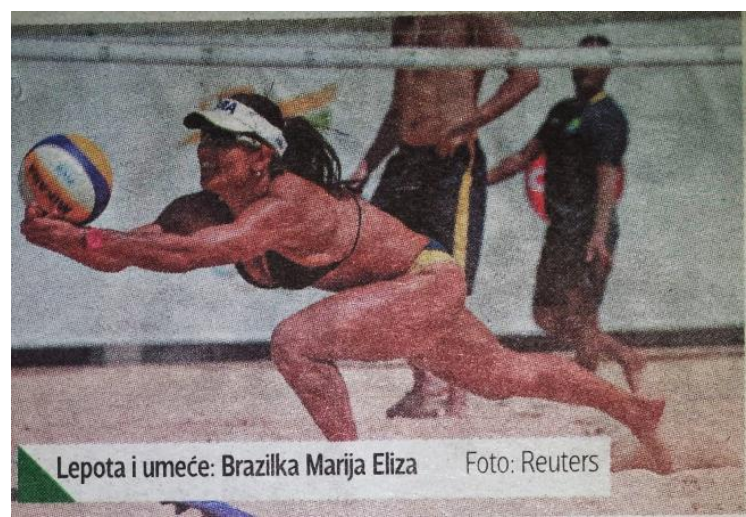

Photo 1. The stereotype about woman as feminine, beautiful, sexual object (photograph) ${ }^{9}$

Text translation: Beauty and talentBrazilian volleyball player Maria Elisa

In addition to the above example of the visual representation of women as sexual objects, narrative texts as well contain such examples. One news published on $27^{\text {th }}$ July 2012 describes a female swimmer as "attractive", "seductive", "subject to male attention" (photo 2).

\footnotetext{
${ }^{9}$ The fact that women are stereotypically portrayed as sexual objects, and their bodies are misused during the modern Olympic Games is substantiated by the example of beach volleyball, which became the Olympic sport in 1996 in Atlanta, and female volleyball players would play this sport in a strictly prescribed, scanty clothes, that is, in a bikini. Since 2012, in London, this rule has changed; volleyball players can wear shorts also. The rules in some of the sports where women had to wear only a skirt or a dress have also been changed (http://content.usatoday.com/communities/gameon/post/ 2012/03/olympic-beach-volleyball-dress-code-gets-a-makeover/1\#.VvvtjuJ97IU).
} 


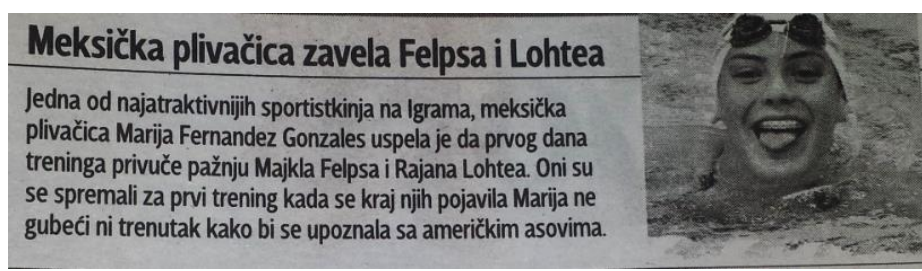

Photo 2. The stereotype about woman as feminine, beautiful, sexual object (narrative text)

Text translation: Mexican swimmer seduced Phelps and Lochte One of the most attractive athletes at the Olympic Games, Mexican swimmer Maria Fernandez Gonzalez managed to draw the attention of Michael Phelps and Ryan Lochte on the first day of training. They were getting ready for the first training when Maria approached them, not losing a moment to meet the American stars.

The stereotype of women as mothers, wives, girlfriends diverts attention from the success of female athletes by talking about their private lives. Such an example was identified in an article published on $28^{\text {th }}$ July 2012, where the success of a Malaysia athlete, who is also the first archery contestant from her country was marginalized by emphasizing her role "of future mother" as more important than her role in the Olympics (photo 3).

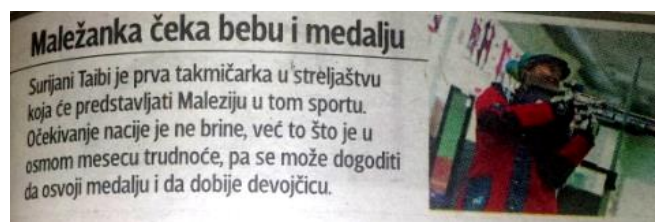

Photo 3. The stereotype of woman as someone's mother, wife, girlfriend (narrative text)

Text translation: Malaysian is waiting for a baby and a medal Suryani Taibi is the first Olympic sports shooter who will represent Malaysia in this sport. She is not worried about the expectation of the nation, but the fact that she us eight months pregnant, so it can happen that she wins a medal and gives birth to a baby girl.

Another example that reinforces this stereotype, and refers to the woman as a girlfriend, has been recognized in an article published on $28^{\text {th }}$ July 2012, where, until recently the number one female tennis player in the world, Wozniacki, was represented through her role of the girlfriend of a famous golfer (photo 4). By depicting her through the role of a girlfriend, her importance as a successful athlete is diminished, while the importance of the private part of her life which associates her with the powerful, famous man is emphasized. This example represents the frequent portrayal of women as "beautiful" or "weaker other". 


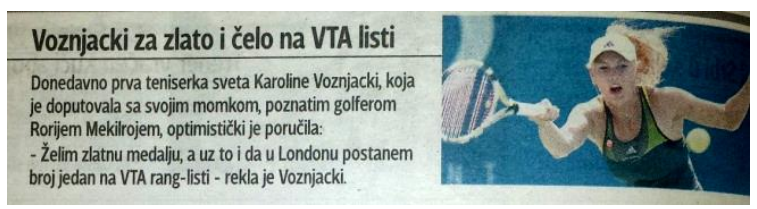

Photo 4. The stereotype of woman as someone's mother, wife, girlfriend (narrative text)

Text translation: Wozniacki aiming for the gold and the first place on the WTA list

Until recently, the world's best female tennis player, Caroline Wozniacki who arrived with her boyfriend, the famous golf player Rory McIlroy, optimistically said: "I want the gold medal, and I also want to become No.I on the WTA list after the London Games" - Wozniacki said.

One of the examples of a female athlete, who is reported about irrespective of her sport activities, was identified during the analysis of a photograph published on $27^{\text {th }}$ July 2012 and it concerns the hairstyle of a famous tennis player (photo 5).

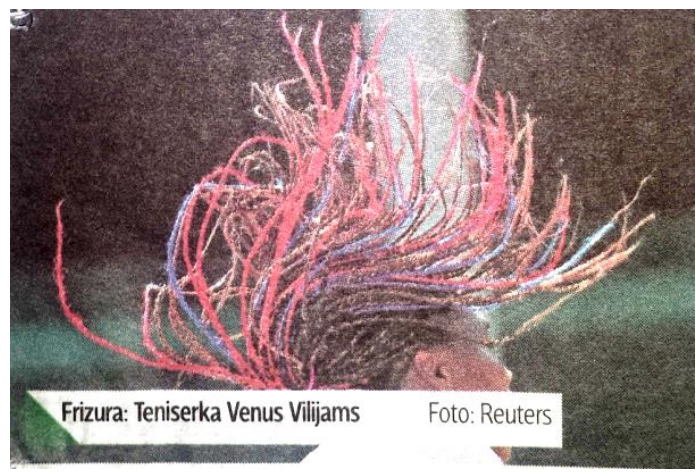

Photo 5. Text is irrelevant; it does not refer to sports activities offemale athletes (photograph)

Text translation: Haircut - Tennis player Venus Williams

Stereotype of women as infantile and emotional was the most common (26.8 percent). One such case was observed during the analysis of the photograph published on July $30^{\text {th }}, 2012$ (photo 6). A Lithuanian contestant, Melutite, was portrayed as emotional and vulnerable in the photograph, while the narrative text said that she "could not hold back tears", which further enhances the emotional connotation. 


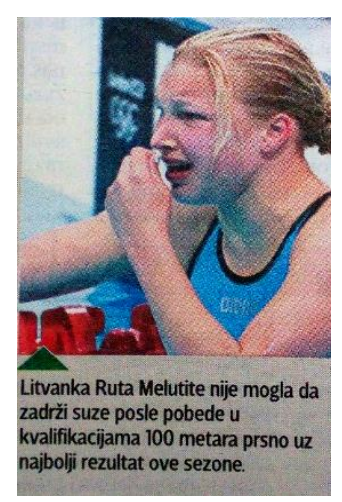

Photo 6. The stereotype of woman as infantile, emotional, irritable (photograph)

Text translation: Lithuanian Ruta Meilutyte could not hold the tears after winning in qualifications for the 100 meter breaststroke with the best result this season.

The abovementioned examples are considered valid by the authors since these illustrate the results shown in the quantitative section of the paper.

\section{DISCUSSION}

Since the first Olympic Games held in $776 \mathrm{BC}$, and since the restoration and establishment of the modern games in 1896 in Athens, up until this day, female athletes have not achieved equal participation, and much less equal media coverage when compared to male athletes. Many mentioned studies all over the world and in Serbia have confirmed that female athletes are marginalized and stereotypically portrayed in the media, and this fact is evidenced by the survey of Serbian media coverage of female athletes, participants of the summer Olympic Games in London in 2012.

Quantitative and qualitative content analysis of the narrative texts and photographs in sports sections, especially in The Olympics Specials and the front pages published during the Olympic Games in London $\left(27^{\text {th }}\right.$ July $-13^{\text {th }}$ August, 2012) in the highest circulation newspaper in Serbia, Blic, the authors proved the starting hypothesis that there are more narrative texts and photographs about male athletes than about female athletes. Overall number of narrative texts and photographs relating to female athletes was 29 percent, compared to the total number of texts; 12.8 percent of these texts were narrative, while 16.2 percent were photographs. It is a far smaller percentage of representation of female athletes in the media in relation to the percentage of female participants at the Olympic Games which was 44.2 percent. More texts were published about male athletes 66.2 percent, 29.4 percent of which were narrative and 36.8 percent of which were photographs. There were 4.8 percent of mixed narrative articles and photographs compared to the total number of articles.

The second hypothesis that the authors tried to prove refers to stereotypical reporting about female athletes, through the narrative texts and photographs, and the following has been identified: the texts are irrelevant, they do not refer to sports activities of female athletes in 10 percent of narrative, and 13.9 percent of photographs; female athlete is portrayed as feminine, beautiful, and as a sexual object, in 1.3 percent of narrative, and 5 
percent of photographs; female athlete is portrayed as someone's mother, wife, girlfriend, in 5 percent of narrative, and 2 percent of photographs; female athlete is portrayed as infantile, emotional, irritable in 10 percent of the narrative, and almost 26.7 percent of photographs. In total, in the narrative texts, female athletes are stereotypically shown in 26.3 percent of cases, and in the photographs, in as much as 47.5 percent of cases. Looking all observed stereotypes and all narrative texts and photographs, the percentage of stereotypical media coverage of female athletes is 73.8 percent, which proves the starting hypothesis. Furthermore, this study observed no difference between reporting on Serbian and foreign female athletes.

Gender inequality in the media coverage of sport events is obvious, ubiquitous, and despite the efforts of the feminist movement and sports activists it is still present. Based on the study presented in this paper, Serbian media are not different from world media. This could be explained by the predominant patriarchal ideology, which dominates much of the world even in the $21^{\text {st }}$ century. Man is a predetermined to be present in the public sphere, which includes sport as well, while women are only present in the private domain.

Although 2012 was a turning point, because for the first time equality was established in sports involving both women and men, there are still more women in traditionally "women's" sports, which put the emphasis on aesthetics (namely, rhythmic gymnastics and synchronous swimming are exclusively female disciplines), while men dominate in traditional "men's" sports, where the emphasis is on strength (for example, martial arts).

In sport, intolerance and discrimination on any ground are not allowed, and therefore sport could be a model in establishing equality in all other spheres of society. Media marginalization of female athletes can lead to the deepening of inequality that, ultimately, keeps the woman out of the public sphere.

Research like this one should contribute to the improvement of the position of women in sports in general, should lead to a more fair media representation, and ultimately empower women and lead them to a greater gender equality, even in the field of media reporting.

\section{REFERENCES}

Alsos, A. G. et al. (2016). Research Handbook on Gender and Innovation. UK, USA: Edward Elgar Publishing.

Berger, J. (1972). Ways of Seeing. London: Penguin Books.

Bishop, R. (2003). Missing in action: Feature coverage of women's sports. Sports Illustrated. Journal of Sport and Social Issues, 27, 184-194.

Branković, S. (2009). Metodi iskustvenog istraživanja društvenih pojava [Methods of Empirical Research of Social Phenomena]. Beograd: Megatrend univerzitet.

Capranica, L. et al. (2005). Newspaper coverage of women's sport during the 2000 Sydney Olympic Games: Belgium, Denmark, France and Italy. Research Quarterly for Exercise and Sport, 76(2), 212-223.

Connell, R. W. (1995). Masculinities. Berkely, CA: University of California Press. 
Cooky, C., Messner, M. A., \& Musto, M. (2015). "It's dude time!” A quarter century of excluding women's sports in televised news and highlight shows. Communication \& Sport, 3(3), 261-287.

Daddario, G. (1994). Chilly scenes of the 1992 Winter Games: The mass media and the marginalization of female athletes. Sociology of Sport Journal, 11, 275-288.

Donnelly, P., \& Donnelly, M. K. (2013). The London 2012 Olympics: A gender equality audit. Toronto, Ontario: Centre for Sport Policy Studies, Faculty of Kinesiology and Physical Education. Retrieved on 5.8.2017 from http://www.playthegame. org/fileadmin/documents/Report_-_Olympic_Gender_Equality.pdf

DeFrantz, A. (2005). Introduction. In W. Wilson (Ed.) Gender in Televised Sports: News and Highlights Shows 1989- 2004, Los Angeles, CA: Amateur AthleticFoundation of Los Angeles.

Đorđić, V., Mršević, Z., Valić Nedeljković, D., Vujanović, S., Milinov, S., \& Pralica. D. (2013). Izveštavanje o sportu: uvođenje rodne dimenzije [Reporting on Sports: Introduction of Gender Dimension]. Kikinda: Centar za podršku ženama.

Đorđić, V. (2013). Prezentacija ženskog sporta u medijima ili ko je Šeli En Frejzer Prajs? [Media Coverage of Women's Sport or Who is Shelly-Ann Fraser-Pryce?] U V. Đorđić (ur.). Izveštavanje o sportu: uvođenje rodne dimenzije [Reporting on Sports: Introduction of Gender Dimension]. Kikinda: Centar za podršku ženama.

Đulijanoti, R. (2008). Sport: kriticka sociologija [Sport: Critical Sociology]. Beograd: Clio.

Embrey, L., Hall, A., \& Gunter, A. (1992). Olympians facing the media. Refractory Girl, $43,10-13$

International Olympic Committee (2016). Factsheet women in the Olympic Movement. Lausanne: International Olympic Committee. Retrieved on 15.3.2016 from https://stillmed.olympic.org/Documents/Reference_documents_Factsheets/Wome n_in_Olympic_Movement.pdf

International Olympic Committee (2014). Olympic Marketing Fact File. Lausanne: International Olympic Committee. Retrieved on 15.3.2016 from http://www.olympic.org/Documents/IOC_Marketing/OLYMPIC_MARKETING _FACT_\%20FILE_2014.pdf

Jakšić, K. M. (2002). Socijalno - psihološki i politički kontekst polnih stereotipa [Social, Psychological and Political Context of Gender Stereotypes]. Nova srpska politička misao, Posebno izdanje 2, 41-58.

Jones, R., Murrell, A. J., \& Jackson, J. (1999). Pretty versus powerful in the sports pages: Print media coverage of US women's Olympic gold medal winning teams. Journal of Sport and Social Issues, 23(2), 183-192.

Lee, J. (1992). Media portrayals of male and female Olympic athletes: Analyses of newspaper accounts of the 1984 and 1988 summer games. International Review forthe Sociology of Sport, 27, 197-219.

Lenskyj, J. H. (1998). Inside sport or on the margins. International Review for the Sociology of Sport, 33, 19-32.

Packer, C., Geh, D. J., Goulden, O. W., Jordan, A. M., Withers, G. K., Wagstaff, A. J., ... $\&$ Webster, C. L. (2014). No lasting legacy: no change in reporting of women's sports in the British print media with the London 2012 Olympics and Paralympics. Journal of Public Health, 37(1), 50-56.

Pedersen, P. M. (2002). Examining equity in newspaper photographs: A content analysis of the print media photographic coverage of interscholastic athletics. International Review for the Sociology of Sport, 37(3-4), 303-318.

Phillips, M. G. (1997). An Illusory Image: a Report on the Media Coverage and Portrayal of Women's Sport in Australia (1996), Canberra: Women's Sport Unit, Australian Institute of Sport.

Pirinen, R. M. (1997). The construction of women's position in sport: A textual analysis of articles on female athletes in Finnish women's magazines. Sociology of Sport Journal, 14, 290-301. 
Pralica, D. \& Milinkov, S. (2013). Slika žene u sportu u medijima u Vojvodini [The Image of Women in Sports in Vojvodina Media]. U V. Đorđić (ur.). Izveštavanje o sportu: uvođenje rodne dimenzije [Reporting on Sports: Introduction of Gender Dimension]. Kikinda: Centar za podršku ženama.

Polley, M. (2014). Sport, Gender and Sexuality at the 1908 London Olympic Games. In J. Hargreaves \& Anderson, E. (ed.). Routledge Handbook of Sport, Gender and Sexuality. New York: Routledge.

Shields, S., Gilbert, L., Shen, X., \& Said, H. (2004). A look at print media coverage across four Olympiads. Women in Sport and Physical Activity Journal, 13(2), 87-99.

Shifflett, B. \& Revelle, R. (1994). Gender equity in sports media coverage: A review of the NCAA News. Journal of Sport and Social Issues, 18, 144-150.

Shih-Chia Chen, S., Duncan, T., Street, E., \& Hesterberg, B. (2016). Differences in Official Athletic Website Coverage and Social Media use Between Men's and Women's Basketball Teams. Sport Journal.

Slater, J. (1998). Changing partners: The relationship between the mass media and the Olympic Games. In Fourth international symposium for Olympic research. London, ON: University of Western Ontario, 49-69.

Smith, M. \& Wrynn, A. (2014). History of Gender and Gender Equality in the Olympics and Paraolympics. Routledge Handbook of Sport, Gender and Sexuality. New York: Routledge, 57-66.

Sola, L. (2009). Šta predstavlja monitoring medija [What Media Monitoring Represents]. Beograd: Priručnik za medije, Ženski INDOK Centar.

The Olympic Museum, Educational and Cultural Services (2013). The Olympic Games in Antiquity. Lausanne: The Olympic Museum. Retrieved on 15.3.2016 from http://www.olympic.org/Documents/Reports/EN/en_report_658.pdf

The Olympic Museum, Educational and Cultural Services (2013). The Modern OlympicGames. Lausanne: The Olympic Museum. Retrieved on 15.3.2016 from http://www.olympic.org/Documents/Reports/EN/en_report_668.pdf

Thomas, L. J. \& Bond, D. K. (2015). Women's Participation in Violent Political Organizations. American Political Science Review, 109 (3), 488-506.

Toohey, K. \& Veal, A. J. (2007). The Olympic Game: A Social Science Perspective, $2^{\text {nd }}$ Edition, CABI.

Vulić, T. i Vujović, M. (2012). Ženska štampa u službi razvoja feminizma u Srbiji [Women's Press for the Purpose of the Development of Feminism in Serbia]. Lipar, časopis za književnost, jezik, umetnost i kulturu, godina XIII/Broj 48, 59-71.

Wensing, E. \& Bruce, T. (2003). Bending the Rules: Media Representations off Gender During an International Sporting Event. International Review for the Sociology of Sport, 38(4), 387-96.

Young, D. (2004). A Brief History of the Olympic Games. Blackwell Publishing.

Zvijer, N. (2012). Sociologija vizuelnog - mogući pravci budućeg razvoja sociologije u Srbiji [Sociology of Visual - Possible Directions of Future Development of Sociology in Serbia]. Sociološki pregled: časopis Srpskog sociološkog društva, Vol. XLVI, no. 3-4, 107-1089.

www.mc.rs/blic-najcitaniji-24-sata-i-alo-ispred-informera.6.html?eventId=67263, retrieved on 23.5.2016.

www.oks.org.rs/takmicenja/olimpijske-igre/letnje-olimpijske-igre/xxx-igre-london-2012, retrieved on 20.3.2016.

www.olympic.org/news/doha-media-workshop-calls-for-commitment-to-lead-the-changein-women-s-sport/245322, retrieved on 20.5.2016.

content.usatoday.com/communities/gameon/post/2012/03/olympic-beach-volleyball-dresscode-gets-a-makeover/1\#.VvvtjuJ97IU, retrieved on 25.5.2016. 


\title{
ЖЕНЕ И ОЛИМПИЈСКЕ ИГРЕ: МЕДИЈСКО ИЗВЕШТАВАЊЕ
}

\author{
Марија Вујовић, Марта Митровић, Невен Обрадовић \\ Универзитет у Нишу, Филозофски факултет, Ниш, Србија
}

\section{Резиме}

Упркос вишевековној феминистичкој борби за родну равноправност и бројним друштвеним, политичким и економским променама у 21. веку, жене су и даље дискриминисане и маргинализоване. Стереотипи о њима опстају, а велику улогу у њиховом стварању и одржавању имају масовни медији. Са таквим родним стереотипима суочавају се и жене спортисткиње. Домен спорта је јавни, а самим тим и мушки домен. Спорт је у последњим деценијама постао и важан медијски производ, па питање медијског представљањаспортских догађаја и родне равноправности постаје актуелно у науци. Бројна истраживања показују да су женски спортови мање медијски покривени, да је мање радијских и телевизијских преноса и извештаја и новинских текстова о женама спортисткињама, али, упркос њима, није дошло до промене хегемонског дискурса на страни мушкараца. Аутори су се у овом раду бавили анализом медијског извештавања о женама учесницама на Летњим олимпијским играма у Лондону 2012. године. Аутори су имали циљ да сходно теоријском полазишту, које уводи у анализу, докажу неравноправни медијски третман жена спортисткиња. Теоријски део рада полази од историјских корена и увођења жена у програм Олимпијаде, пружајући увид у вишевековну борбу жена за једнака права, која су мушкарцима рођењем била загарантована. Даље, аутори интерпретирају разнолика истраживања из области која је предмет овог рада, анализирајући резултате истраживања аутора који су се бавили учешћем и медијским представљањем жена на Олимпијским играма. Сва она, са већим или мањим разликама, доводе до готово уједначеног закључка: жене и даље јесу маргинализоване у спортском извештавању, а и онда када нису, квалитет извештавања о женским спортовима и спортисткињама најчешће је упитан, јер је углавном стереотипан. Упркос повећању процента учешћа жена у свим спортским дисциплинама, па и у дисциплинама на Олимпијским играма, извештавање медија о женама спортисткињама не прати тај тренд. То доказује и истраживање у овом раду. Упркос готово изједначеном броју спортиста и спортисткиња на Летњим олимпијским играма у Лондону 2012. године, у години када су жене спортисткиње први пут освојиле могућност равноправног учешћа у свим спортским дисциплинама у којима се такмиче и мушкарци спортисти, медијско представљањеније било уједначено. Квантитативно-квалитативном анализом садржаја шест стотина двадесет пет наративних текстова и фотографија у спортским рубрикама, посебно у оквиру Олимпијског специјала и насловним странама, објављеним у периоду трајања Олимпијских игара у најтиражнијим новинама у Србији - „Блицу”, аутори су доказали постављену хипотезу да је више наративних и визуелних текстова о мушкарцима спортистима него о женама спортисткињама. Доказана је и друга хипотеза, која се односи на стереотипно извештавање о женама спортисткињама, кроз наративне текстове и фотографије, а препознати су следећи: Текстови су нерелевантни, жена спортисткиња је приказана као женствена, лепотица, сексуални објект, жена спортисткиња је приказана као нечија мајка, супруга, девојка, жена спортисткиња је приказана као инфантилна, емотивна, раздражљива. Родна неједнакост у медијском спортском извештавању је очигледна, свеприсутна и, упркос напору феминистичког покрета и спортских активиста, још непревазиђена. Српски медији се, су- 
дећи према истраживању у раду, не разликују од светских. Ово би се могло објаснити свепрожимајућом патријархалном идеологијом, која и у 21. веку опстаје. Мушкарцу је предодређена јавна сфера, која обухвата и спорт, а жени приватни домен. Дакле, нема сумње да медији кроз своје наративне и визуелне поруке граде родну хијерархију у спорту, у којој доминирају „снажни” мушкарци над „слабим” женама, а мушки спорт вреднују више од женског. 